\title{
Transpiration and Behaviour of Stomata in Halophytes.
}

\section{E. MARION DELF. \\ With thirteen Figures in the Text.}

I. INTRODUCTION.

ALT-MARSH plants are of some interest because, whilst apparently aquatic in habit, they show features, such as succulence, reduction in leaf surface, and even hairiness (in tropical forms), which are commonly associated with a distinctly xerophilous habit.

As early as I 888 Lesage noticed that many plants common to littoral and inland regions were constantly rather more succulent when in the former position, and this led him to undertake an extensive series of culture experiments in order to see whether the thicker leaves could be produced artificially by watering with a solution of sodium chloride. The results were variable, but in Lepidium sativum and some other cases there was a distinct increase in thickness and a tendency towards diminution in the leaf surface. In I89 I Schimper found that watering inland plants with saline solutions caused a distinct reduction in the rate of transpiration, and in some cases appeared to have an injurious effect on assimilation; and that in certain cases plants watered with weak solutions showed a distinct accumulation of chlorides within the mesophyll cells of the leaf. The explanation advanced by Schimper and accepted by Pfeffer ${ }^{1}$ and Dr. Ludwig Jost ${ }^{1}$ was to the effect that these plants are unable to absorb water freely from the soil, owing to the danger of thereby bringing into the tissues injurious amounts of salts. Since the absorption is thus limited, the transpiration must needs also be diminished, and this is brought about by the various xerophilous adaptations to which allusion has already been made; or in the words of Schimper, the watery habitat must be regarded as being 'physiologically dry'.

${ }_{1}$ Pfeffer, Phys. of Plants, Eng. Edition, vol. i, p. I55. Cp. also Jost, Lectures on Plant Physiology, 1907, Eng. Edition, p. 97 .

[Annals of Botany, Vol. XXV. No. XCVIII. April, 19II.]

K k 
In 1894 Stahl published an account of his cobalt paper method, and he found by means of this test that in many halophytes there was a considerable and sustained rate of transpiration. He asserted that in these plants the stomata appear to have lost the power to close, as is often the case in freshwater marsh plants. According to Stahl, the succulent habit has been developed as a compensation to reduce the transpiration, which can no longer be regulated by the stomata.

In 1897 Rosenberg repeated a number of Stahl's experiments, but worked in the field, testing each leaf immediately after detaching it from the plant. By this means he found that whereas immediately after being detached the leaf produced a pink coloration in from one to three minutes, thus showing a rapid rate of transpiration, yet five or ten minutes after being detached the same leaf gave little or no coloration when in contact with the cobalt paper for ten or even twenty minutes. Some of the plants were uprooted and brought to a laboratory, and on testing, gave the slower rate of transpiration; microscopic examination showed that in nearly every case the stomata were closed. Rosenberg suggests that this may have been due either to want of water, or to the darkness to which they were exposed while in the collecting-tin; but in either case his results clearly show that, contrary to the opinion of Stahl, the stomata in halophytes have some power of movement, whilst the results of both Stahl and Rosenberg are in opposition to the commonly accepted view of Schimper, that halophytes are essentially xerophilous in habit.

The present paper is the outcome of some experiments performed at Erquy in September, 1906, at the suggestion of Professor Oliver. Most of the work has been done in the laboratory at Westfield College, but in July, I909, owing to the kindness of Professor Seward, some observations were made at the Cambridge Botanic Laboratory. My thanks are due to Professor Oliver for supplies of fresh material of Salicornia anmua, and for advice and continued interest throughout.

In the following pages some account is given of measurements of the rate of water loss in certain typical halophytes, and of the power which these plants possess to absorb water by means of their green surface. Some observations on the stomata of Salicornia annua and Aster tripolium are also recorded, and these in the main support Rosenberg's conclusion that the guard cells possess the power of movement.

\section{Measurements of Loss of Water due to Transpiration.}

(a) Method of determining transpiring areas. The method most commonly employed in the determination of surface areas was that of tracing the outline on squared paper, and thus estimating the total surface exposed. When mesophytic leaves were used the tracing was done before detaching the leaf, or, where this was not possible, immediately after its removal from 
the plant : this was done in order to avoid as far as possible the shrinkage which has been demonstrated to take place in many leaves even before withering becomes perceptible. ${ }^{1}$

For the very small boat-shaped leaves of Suacta, and for the jointed swollen stems of Salicomia, I have used methods which were originally suggested to me by Mr. T. G. Hill. In the case of Suaeda ten or twelve leaves were cut off quickly from the stem and placed side by side on paper ruled in millimetre squares. The outline of the whole was then traced with a sharp pencil, and twice the area marked out was taken as a rough approximation to the transpiring surface of the leaves. This was repeated until all the leaves from the experimental shoot had been measured. The surface area of the stem, if this was herbaceous, was also included in the total transpiring surface thus estimated.

In the case of Salicornia, a number of measurements of the diameter were made by means of a micrometer screw reading to $\frac{1}{10} \overline{\mathrm{mm}}$.; usually one measurement was made near the upper part of each internode. The
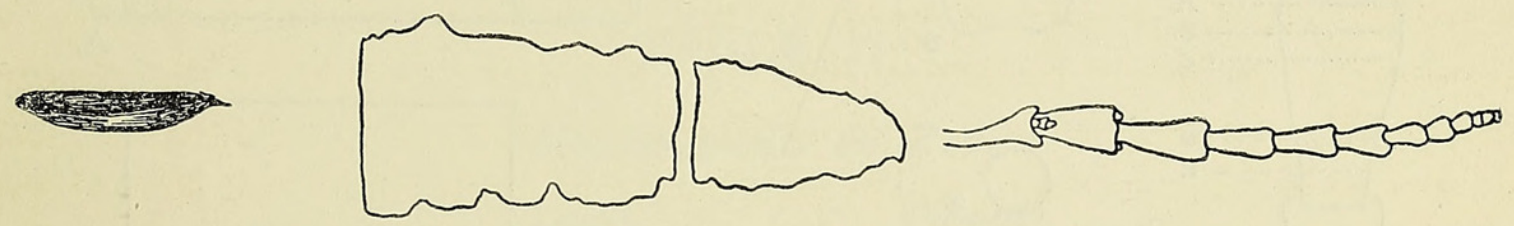

Fig. I. Single leaf of Suaeda maritima.
FIG. 2. Outline obtained by placing leaves of Suaeda side by side, and tracing area covered on squared paper.
FIG. 3. A shoot or Salicornia annua with uneven internodes.

height of the shoot was measured, and the transpiring surface was then estimated as [average diameter $\times \pi \times$ height]. Now the diameter varied considerably amongst the specimens which were examined. Some possessed stems with a nearly even cylindrical surface, and tapering only slightly at the tip; others showed an uneven surface, each segment being wider above than below, and more or less laterally compressed in the upper part: the stem often tapered considerably at the tip. As far as possible, even, bluntly ending stems were chosen for experiment, but in the specimens with tapering internodes a very fair average diameter can be found by measuring just below the broadest region, taking if necessary the mean of the narrower and wider dimensions at that level. For example, in a small plant with markedly tapering internodes the following figures were obtained in measuring the internode next above the hypocotyl :-

1 Thoday, D. ('09) : Experimental Researches on Vegetable Assimilation and Respiration, V. Proc. Roy. Soc., B., vol. lxxxii, 1909. 


\section{TABLE I}

Measurements of Diameter of a Single Internode at Different Levels.

Level.
A
B
C
D
E

(i)
$3.25 \mathrm{~mm}$.
$3.37 \quad "$,
$2 \cdot 75 \quad "$
$2.35 \quad "$,
$2.1 \quad "$,

(ii)

$3.8 \mathrm{~mm}$.

$3 \cdot 7$,

$3 \cdot \mathrm{I}$,

$2 \cdot 55$,

2.0I,

Average diameter $2.898 \mathrm{~mm}$.

The levels at which the measurements were made are shown in Fig. 4 (i). At the level B the cross-section is roughly elliptical in outline; at the level $\mathrm{E}$ the outline of a cross-section would be almost perfectly circular. In this experiment measurements of the greatest and least diameter
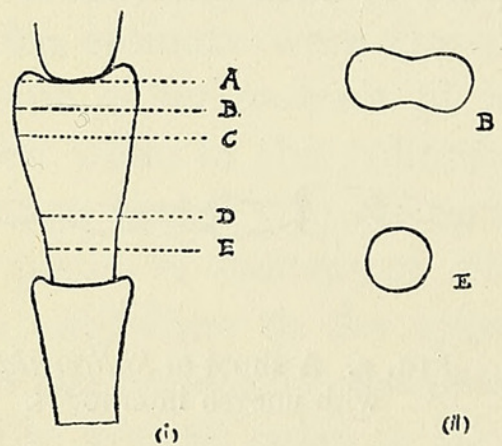

(ii)

FIG. 4. (i) Internode of a shoot of Salicornia annua, from which measurements recorded in Table I were made, at the levels A, B, C, D, E. In (ii) are shown the outlines of cross-section at the levels $\mathrm{B}$ and $\mathbf{E}$.

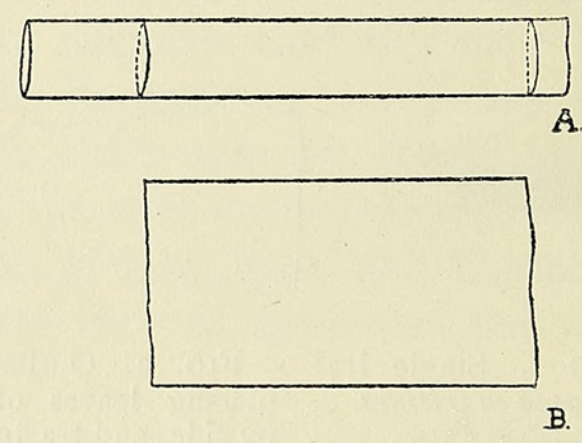

FIG. 5. Showing at A the short glass rod from which the celluloidin film B was obtained.

were made at each level (Table I, columns (i) and (ii)). The mean of all these readings is nearly $2.90 \mathrm{~mm}$., and the mean of the two readings at the level $\mathrm{C}$ is $2.92 \mathrm{~mm}$. Thus for all practical purposes the mean diameter just below the widest part of the internode represents the mean diameter for that internode. These readings can, with a little practice, be made easily and quickly on the growing shoot, and thus errors due to shrinkage during manipulation are avoided, but some care must be taken not to bruise the surface of the plant when adjusting the micrometer screw.

At first sight this method may seem too rough to be of any value for quantitative work, but the following experiments show that the error is less than might have been anticipated.

A length of $3 \mathrm{~cm}$. was first marked off with Indian ink on a short glass rod. The distance between the marks was read with a lens magnifying ten times, and the mean of three readings gave the mean length 
between the marks. The diameter was measured with a micrometer screw. The rod was now dipped into a solution made by dissolving Schering's celluloidin in equal parts of alcohol and ether. On withdrawing the rod and turning it gently for one to two minutes, a firm film was formed over the whole of the glass rod. This was now cut as nearly as possible above the Indian ink marks, and split along its length with a sharp knife, so that a small and nearly rectangular film was removed from the measured region of the glass rod. The film was immediately placed with the inner side downwards upon paper ruled in millimetre squares, and the area found. After a few trial experiments it was possible to make a film which gave the area correct to within $2 \%$.

Fig. 5 shows at A a short glass rod marked with Indian ink at two places, $3 \mathrm{~cm}$. apart; and at $\mathrm{B}$ the outline of the film which was removed from this region and spread out on squared paper. Table II shows the preliminary measurements made on the glass rod, and the surface area found from these measurements and from the film, respectively.

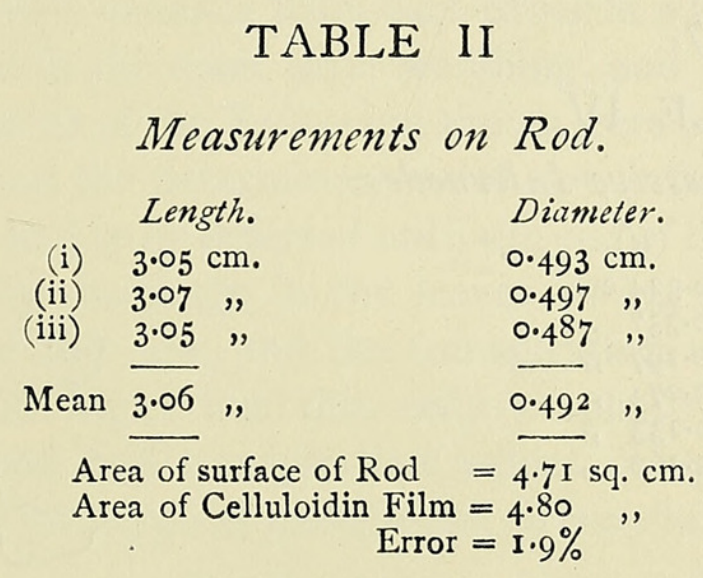

Using now the same solution of celluloidin and the same time of hardening the film ( $3 \mathrm{~min}$.), this process was repeated, a shoot of Salicornia being substituted for the glass rod. The manipulation was more difficult in this case, owing to the delicate nature of the epidermis and the soft texture of the outer tissues; the crevices at the nodes between the leaf segments and the stem also made it difficult to remove the film intact. However, after a few trials good films were obtained, and these gave areas sufficiently close to those obtained by calculation from measurements with the micrometer screw.

Table III shows at A the measurements obtained from one such shoot of Salicornia, and at B the surface areas obtained by estimation from these figures and from the celluloidin film removed from the surface, and outlined in Fig. 6. 


\section{TABLE III}

A. Diameters of Successive Internodes.

(i)

$0.354 \mathrm{~cm}$.
$0.334 \quad "$,
$0.338 \quad "$,
$0.326 \quad "$,
$0.28 \mathrm{I}, "$,
$0.268, "$,
$0.184, "$
$0.160, "$

B. Results.

$$
\begin{aligned}
& \text { Height of Shoot }=5.30 \mathrm{~cm} . \\
& \text { Mean Diameter of Shoot }=0.300, " \\
& \text { Surface Area of Shoot }=4.99 \mathrm{sq} . \mathrm{cm} . \\
& \text { Surface Area of Film }=5.00,
\end{aligned}
$$

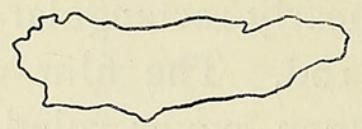

FIG. 6. Outline obtained by removing celluloidin film from shoot of Salicornia, and stretching it upon squared paper.

In a second experiment of the same kind the film was removed without injury to the shoot, which was therefore dipped again into the solution, so that a second film was obtained. The measurements are shown in Table IV, and the films in Fig. 7 .

\section{TABLE IV}

\section{A. Diameters of Successive Internodes.}

(i)

$0.288 \mathrm{~cm}$.

0.302,

0.275,

0.237 "

0.194,

0.162 ,

B. Results. (ii)

$0.324 \mathrm{~cm}$.

0.337,

0.297 ,

0.274, ,

0.233,

0.162,

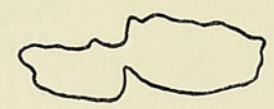

$$
\begin{aligned}
& \text { Height of Shoot } \quad=0.257 \mathrm{~cm} \text {. } \\
& \text { Mean Diameter of Shoot }=3.35 \text {, } \\
& \text { Surface Area of Shoot }=2 \cdot 70 \text {, } \\
& \text { Surface Area of Film (I) }=2 \cdot 70 \text {, } \\
& \text { Error }=0.7 \%
\end{aligned}
$$

The most obvious source of error in working with a celluloidin film is the difficulty of removing the film when it is sufficiently firm not to suffer distortion, and is yet not wrinkled or shrunken. The preliminary experiments with a glass rod showed that if the film is not firm, it may stretch in its removal by as much as $20 \%$ of the true area; on the other hand, in removing a film from such a stem as that of Salicornia, the edges of the part first lifted sometimes shrivel, and then a very low value for the surface area would be obtained. It will be seen, however, that good films successfully removed gave a very fair approximation to the calculated areas in the case of the glass rod, and they may also show a near approximation to the actual surface area in the case of the shoot. On the whole, then, it appears 
that the calculated surface area of Salicornia shoots is somewhat high, but may probably be accurate to within $2-3 \%$

( $\beta)$ Observations on the transpiration of detached shoots during first few hours of withering. Through the kindness of Professor Oliver, a number of experiments were performed in the field at a salt marsh near Erquy, in the early part of September, I906. The plants used were a green and a red form of Salicornia anmua, Suaeda maritima, Atriplex portulacoides, and as a control, small plants of Mercurialis anmua, which were taken from one end of a neighbouring cornfield, to serve as a typical mesophyte.

Early in the afternoon of September 8, clumps of Mercurialis anmua, Salicornia anmua (both the 'apple green' and 'crimson plain 'varieties), and of Suaeda maritima were collected from their respective stations, and brought to the laboratory. Five shoots of Mercurialis were detached, set upright with the stems embedded in a shallow tin of wax mixture, and weighed. Ten shoots of each kind of Salicornia were set up similarly, the crimson plain shoots being in one tin together, and the apple green in a separate tin also together; and six small plants of Suaeda were placed in the same way at a little distance from each other in a fourth tin of wax. All the tins were placed in the open, after weighing, and the plants were left to wither. The dimensions of the Salicornia shoots were found immediately after the first weighing, but the determinations of the surface area of Suad a and Mercurialis shoots had to be deferred until the end of the experiment. Since there is undoubtedly shrinkage in the leaves owing to water loss, the area estimations will be too low, and the transpiration values per $100 \mathrm{sq} . \mathrm{cm}$. correspondingly too high; but this only emphasizes the fact that the halophytes examined had transpiration values comparable with or even greater than that of the typical mesophyte, Mercurialis annua.

\section{TABLE V}

Loss of Weight in Detached Shoots of Mercurialis, Salicornia, and Suaeda.

\begin{tabular}{|c|c|c|c|c|c|c|c|c|c|c|c|c|}
\hline & \multicolumn{3}{|c|}{ Mercurialis. } & \multicolumn{3}{|c|}{ Apple Green Sal. } & \multicolumn{3}{|c|}{ Crimson Sal. } & \multicolumn{3}{|c|}{ Suaeda. } \\
\hline & Hour. & Time. & $\begin{array}{l}\text { Actual } \\
\text { Loss. }\end{array}$ & Hour. & Time. & $\begin{array}{l}\text { Actual } \\
\text { Loss. }\end{array}$ & Hour. & Time. & $\begin{array}{l}\text { Actual } \\
\text { Loss. }\end{array}$ & Hour. & Time. & $\begin{array}{l}\text { Actual } \\
\text { Loss. }\end{array}$ \\
\hline \multirow{6}{*}{$\begin{array}{l}\text { (I) } \\
\text { (2) } \\
\text { (3) }\end{array}$} & $\begin{array}{l}\text { p.m. } \\
\text { I } 2.5\end{array}$ & hrs. & grm. & $\begin{array}{l}\text { p.m. } \\
\text { I 2.I0 }\end{array}$ & & grm. & $\begin{array}{l}\text { p.m. } \\
2\end{array}$ & & & $\begin{array}{l}\text { p.m. } \\
\text { 2.I } 5\end{array}$ & & grm. \\
\hline & 2.35 & $2 \frac{1}{2}$ & 0.075 & 2.45 & $2 \frac{1}{2}$ & 0.106 & 3.30 & $I \frac{1}{2}$ & $0.05^{8}$ & 3.45 & $I \frac{1}{2}$ & 0.106 \\
\hline & 4. IO & $\mathrm{I} \frac{1}{2}$ & 0.025 & 4.20 & $\mathrm{I} \frac{1}{2}$ & 0.105 & & $\mathrm{I} \frac{1}{2}$ & 0.019 & 5.15 & $I \frac{1}{2}$ & 0.019 \\
\hline & $5 \cdot 5^{\circ}$ & $1 \frac{2}{3}$ & 0.017 & 6.30 & & 0.007 & 6.50 & I $\frac{5}{6}$ & 0.007 & 6.45 & $1 \frac{1}{2}$ & 0.024 \\
\hline & \multicolumn{3}{|c|}{$\begin{array}{l}\text { Surface Area } \\
45 \cdot \mathrm{I} 4 \mathrm{sq} . \mathrm{cm} \text {. }\end{array}$} & \multicolumn{3}{|c|}{24.43 sq. $\mathrm{cm}$. } & \multicolumn{3}{|c|}{ I $7 \cdot 44$ sq. $\mathrm{cm}}$. & \multicolumn{3}{|c|}{$40 \cdot 3^{8}$ sq. cm. } \\
\hline & \multicolumn{3}{|c|}{$\begin{array}{l}\text { Loss per hour per } \\
\text { I } 00 \text { sq. } \mathrm{cm} \text {. }\end{array}$} & \multicolumn{3}{|c|}{$\begin{array}{l}\text { Loss per hour per } \\
\text { 100 sq. } \mathrm{cm} .\end{array}$} & \multicolumn{3}{|c|}{$\begin{array}{l}\text { Loss per hour per } \\
\text { I00 sq. cm. }\end{array}$} & \multicolumn{3}{|c|}{$\begin{array}{l}\text { Loss per hour per } \\
\text { IOO sq. } \mathrm{cm} .\end{array}$} \\
\hline $\begin{array}{l}(1) \\
(2) \\
(3)\end{array}$ & \multicolumn{3}{|c|}{$\begin{array}{l}0.066 \mathrm{grm} . \\
0.037 ", \\
0.022,\end{array}$} & \multicolumn{3}{|c|}{$\begin{array}{l}0.173 \mathrm{grm} . \\
0.286, " \\
0.038, "\end{array}$} & \multicolumn{3}{|c|}{$\begin{array}{l}0.226 \mathrm{grm} . \\
0.072 " 1 \\
0.027\end{array}$} & \multicolumn{3}{|c|}{$\begin{array}{l}0.350 \mathrm{grm} . \\
0.062 ", \\
0.079,\end{array}$} \\
\hline
\end{tabular}


During the whole time of the experiment the plants were exposed outside the laboratory in a position sheltered from wind and from the morning sun; direct sunlight fell upon the plants only after I 2 p.m., and until about $4.3^{\circ}$ p.m. It will be seen that the weighings of the crimson Salicornia and Suaeda were begun later in the day than those of the other two plants; and accordingly both these plants show a higher initial transpiration value than the 'apple green' Salicornia. The maximum rate of transpiration per hour per 100 sq. $\mathrm{cm}$. was attained by Suacda. If the water content per $100 \mathrm{sq} . \mathrm{cm}$. be taken as a rough measure of the degree of succulence of the plant, it will be seen (see Table VI) that Suaeda was also the most succulent of the plants examined, and it thus appears at once that the succulent habit is not necessarily due to or even coincident with a reduced rate of transpiration.

\section{TABLE VI}

\section{Degree of Succulence of Mercurialis, Salicorma, and Suaeda.}

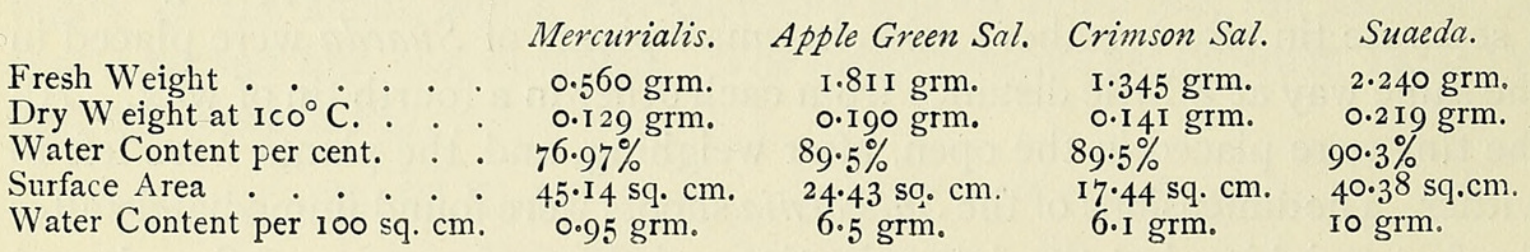

During the course of the experiment there is, except in the case of 'apple green' Salicornia, an initial transpiration value which quickly shows a con-

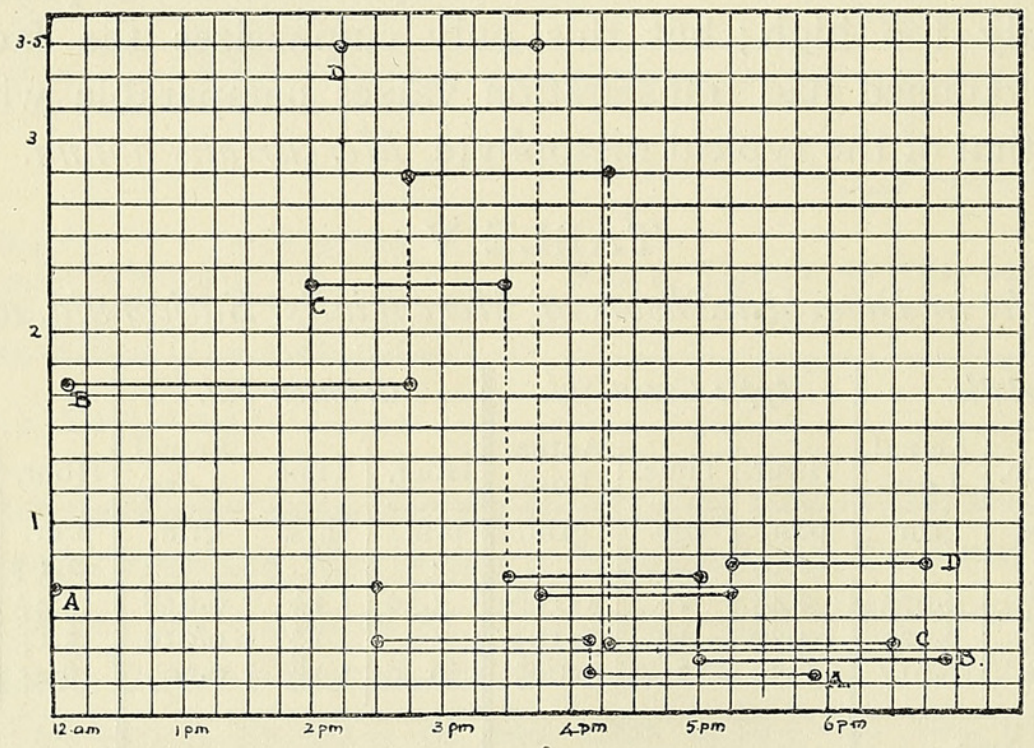

FIG. 8. Curves showing average transpiration per hour per $100 \mathrm{sq} . \mathrm{cm}$. in cut shoots not supplied with water. $\mathrm{A}=$ Mercurialis annua ; $\mathrm{B}=$ Salicornia annua (crimson red); $\mathrm{C}=$ Salicornia annua (apple green); $\mathrm{D}=$ Suaeda maritima. Ordinates represent loss of weight in grammes ; abscissae represent time intervals of one hour. Figures taken from Table V.

siderable diminution. In Fig. 8 this is shown graphically; the horizontal line representing the average transpiration during any given period of time. 
The Mercurialis and 'apple green' Salicornia were started practically simultaneously; both have the power of closing their stomata on wilting, ${ }^{1}$ but in Salicornia, notwithstanding this, there is seen a considerable rise in the cuticular transpiration during the early afternoon; and this probably only fell off when increased sap concentration acted as an inhibiting factor, diminishing the possible water loss. Suaeda and 'crimson red' Salicornia were started under the atmospheric conditions which caused the increase in transpiration in Salicornia, and they show only a steady decrease during the afternoon hours.

Further experiments at Erquy, both on growing and on detached shoots, led to the conclusion that under ordinary conditions transpiration in the halophytes mentioned is of considerable magnitude; that in dry air it would be greater than the supply of water from the roots would allow; and that in nature this is to a large extent obviated by the fact that the layers of air next to the damp earth of a salt marsh contain much more water vapour than the higher layers, whilst periodic flooding renders a large amount of absorption of water possible over the whole surface of the plant; but this point will be considered more fully subsequently.

In July, I909, with the permission of Professor Seward, further experiments were made at the Cambridge Botanical Laboratory. Some healthy and smooth-stemmed plants of Salicornia annua were very kindly sent by Professor Oliver from Cley; these were green, and no forms approaching the 'crimson red 'type were available. The experiments were made in the dry air of the laboratory (humidity 60\%), but more precautions were used than had been possible in the field laboratory at Erquy; an accurate chemical balance was used throughout.

On July 23 the transpiration of a detached shoot of Salicornia annua was compared with that of leaves of Sedum spurium and Vicia cracca. The former was the most suitable succulent xerophyte and the latter the most convenient mesophyte at hand.

A healthy shoot of Salicornia was measured, detached, and the cut end sealed with wax mixture of low melting-point, and a small loop of cotton was fixed to this end. It was then suspended in nearly saturated air under a bell-glass, while two leaves of both Sedum and Vicia were treated similarly. When all were hung up in the saturated air, they were weighed in order and the time noted ; they were subsequently weighed at intervals of 20 minutes, during which time they had been suspended in bright diffuse light in the ordinary still air of the laboratory.

The following table shows the loss of water in these leaves at intervals of 20 minutes during the first three hours of exposure. Throughout this period the temperature varied from $19.8^{\circ} \mathrm{C}$. to $20.8^{\circ} \mathrm{C}$, and the humidity from $55 \%$ to $57 \%$, chiefly owing to intermittent clouds : between 12.50 p.m. 1 Cp. Rosenberg ('97), See also later experiments. 
and 6 p.m. there was also fitful sunshine, but the observations were then made at longer intervals of time. At the end of the experiment the Sedum and Salicornia appeared fresh, but very slightly perceptibly flaccid, whilst the Vicia was very much withered and indeed almost brittle. These figures are shown graphically in Fig. 9.

\section{TABLE VII}

Loss in Weight of Salicornia, Vicia, and Sedum for given Time Intervals, per 100 sq. cm.

\begin{tabular}{|c|c|c|c|c|c|c|}
\hline Time. & Temp. & Humidity. & Sedum spurium. & Sal. anmua. & Vicia cracca. & Water. \\
\hline $\begin{array}{l}9.40 \text { a.m. } \\
\text { IO ", } \\
\text { I0.20 ", } \\
\text { I } 0.40, ", \\
\text { I I } ", \\
\text { I I.20 ", } \\
\text { I I.40 ", } \\
\text { I } 2.40 \text { p.m. } \\
6.5, ", \\
6.30, ",\end{array}$ & $\begin{array}{l}19.8^{\circ} \mathrm{C} . \\
20 ", \\
20 \quad ", \\
20.1 ", \\
20.2 ", \\
20.3, " \\
20.8, " \\
20.3, " \\
2 \text { I ", } \\
2 \text { I ", }\end{array}$ & $\begin{array}{l}57 \% \\
55,, \\
55, " \\
56, " \\
55,, \\
55,, \\
57,, \\
62, " \\
51, \\
65,,\end{array}$ & $\begin{array}{l}0.084 \mathrm{grm} . \\
0.063 \quad ", \\
0.049 ", \\
0.046 ", \\
0.046 ", \\
0.049 ", \\
0.115 \quad ", \\
0.699 ", \\
0.038, "\end{array}$ & $\begin{array}{l}0.075 \mathrm{grm} . \\
0.058 \quad, \\
0.067 \quad ", \\
0.067 \quad ", \\
0.058 \quad ", \\
0.042 \quad ", \\
0.091 \quad ", \\
\mathrm{I} .099 \quad ", \\
0.042 \quad ",\end{array}$ & $\begin{array}{l}0.057 \text { grm. } \\
0.028, " \\
0.017 ", \\
0.017, " \\
0.013 ", \\
0.009 ", \\
0.018, ", \\
0.109, ", \\
0.005, "\end{array}$ & 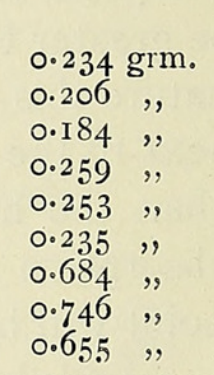 \\
\hline & \multicolumn{2}{|c|}{$\begin{array}{l}\text { Surface Areas } \\
\text { Fresh Weight }\end{array}$} & $\begin{array}{c}\mathrm{I} 4.3^{2} \text { sq. cm. } \\
0.93^{2} \text { grm. }\end{array}$ & $\begin{array}{l}5.96 \mathrm{sq} . \mathrm{cm} . \\
0.43^{2} \mathrm{grm} .\end{array}$ & $\begin{array}{c}50.54 \text { sq. cm. } \\
0.487 \text { grm. }\end{array}$ & 25.49 sq. cm. \\
\hline
\end{tabular}

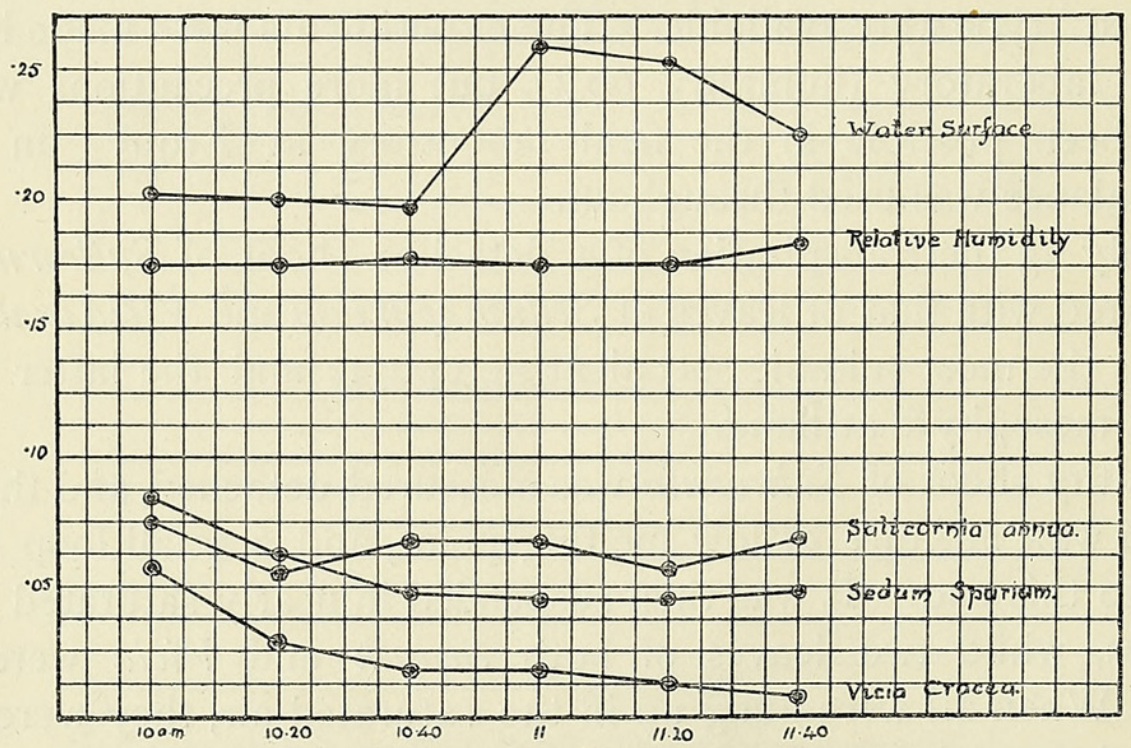

FIG. 9. Curves showing loss of water by weight per 100 sq. $\mathrm{cm}$. in Salicornia, Vicia, and Sedum for first two hours of withering. Abscissae represent time intervals of 20 minutes; ordinates represent loss in weight in grammes. Figures taken from Table VII.

It will be seen that there is a striking resemblance between the behaviour of the two succulent types, and that the transpiration of both of these considerably exceeds that of the mesophytic type. It should, however, be observed that in the case of both Sedum and Vicia, the leaves used 
were detached from the parent plant and were probably transpiring at a rate a ppreciably greater than would have been the case had they been attached to a shoot bearing other leaves. This phenomenon has been observed by Pringsheim ${ }^{1}$ in certain species of Sedum and other succulent plants which store up water in the adult leaves, and it seems probable that the same would apply to mesophytes, although this point was not determined. In the case of a species of Mesembryanthemum ${ }^{2}$ observed by me, a detached adult leaf transpired per unit area from two to four times as freely when withering, as a shoot of the same plant under the same conditions, but bearing two young as well as two adult leaves. If this were true in the case of the Sedum and Vicia mentioned in Table VI, it would make the contrast between the rates of transpiration in these cases only more strikingly remote from that of Salicornia anmua.

In Table VIII the proportional or 'relative' transpiration values are given for the three plants, taking the loss per hour per Ioo sq. cm. in a freely evaporating water surface as I00. The variations now shown in transpiration must be independent of the purely physical effect of the environment. ${ }^{3}$

\section{TABLE VIII}

Relative Transpiration per Hour per Ioo sq. cm. of Sedum, Salicornia, and Vicia.

$\begin{array}{cccc}\text { Sedum. } & \text { Salicornia anmia. } & \text { Vicia cracca. } & \text { Water Surface. } \\ 36 & 32 & 26 & 100 \\ 30 & 28 & 14 & 100 \\ 27 & 36 & 9 & 100 \\ 17 & 26 & 6 & 100 \\ 18 & 23 & 4 & 100\end{array}$

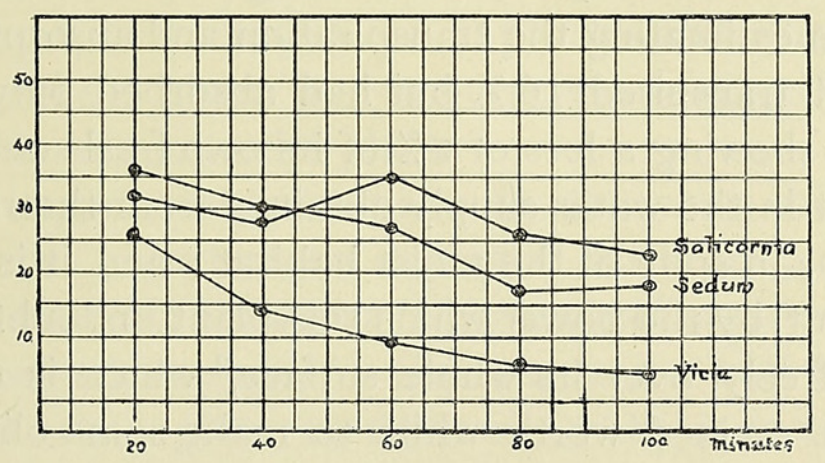

FIG. Io. Curves showing relative transpiration during withering of Salicornia, Sedum, and Vicia. Ordinates represent figures shown in Table VIII; abscissae represent time intervals of 20 minutes each.

1 Pringsheim, E. ('06): Wasserbewegung und Turgorregulation in welkenden Pflanzen. Jahrbücher für wiss. Bot., 1906 .

2 Probably a variety of $M$. speciosum.

${ }^{3}$ Cp. Livingston ('06): The Relation of Desert Plants to Soil, Moisture, and to Evaporation. 


\section{ABsorption OF WATER BY GREEN PARTS IN HALOPHYTES.}

In Fig. 9 the relative ${ }^{1}$ rates of transpiration during withering are shown graphically. It will be seen that, apart from effects of variations in the physical environment, the two succulent types, Salicornia and Sedum, show a water loss not only greater but more constant than that of the Vicia leaf. Probably the stomata in each case were closed, at any rate after the first half-hour, but in the first two plants, on account of the lack of cuticle and perhaps also the presence of aqueous tissue, this is an insufficient check to the transpiration in the dry air of the laboratory, although the wilting which ensues is less obvious than in the case of a mesophyte.

Notwithstanding the comparatively rapid transpiration any species of Sedum can be grown successfully in a dry atmosphere if a supply of water is given to the roots; but in my experience this is not true of Salicornia and some other halophytes; on the contrary, this plant appears unable to absorb enough water by its roots to make good the loss due to transpiration in the dry air of a laboratory

On July I9, I909, a test experiment was performed to determine the transpiration and absorption of a young, healthy, and uninjured Salicornia plant in the comparatively dry air of the Cambridge Botanical Laboratory. The plant, which appeared to be perfectly turgid, was washed carefully free from soil, dried, weighed on an accurate balance, and placed with the root dipping into a known amount of water in a weighed vessel. A control vessel of water stood near, and was used to give the evaporation from the exposed water surface in the experimental vessel. After an interval of two hours, the plant was removed, dried, and weighed, and the vessels of water also weighed. On estimating the transpiration and absorption it was found that the plant had transpired $16 \%$, but had absorbed only $14 \%$ of its own fresh weight, thus showing a loss of $2 \%$ of its own fresh weight.

Such a deficit in the water supply obtained from the roots is, probably, common in nature, in spite of the moist habitat; and it is compensated, at least to some extent, by the power which this plant undoubtedly possesses of absorbing water freely over its whole surface, ${ }^{2}$ which is capable of being easily wetted. It seemed worth while to make some observations on the absorptive power in this and other plants.

Three young plants of Salicornia anmua were cut just above the level of the highest internode which was at all faded, and the cut ends were sealed with wax. The plants were then dipped into water, dried thoroughly with blotting-paper and a soft cloth, and weighed separately. They were then

1 Livingston ('06): The Relation of Desert Plants to Soil, Moisture, and Evaporation.

2 Cp. Pfeffer, W. ('00): The Physiology of Plants, English Edition, vol. i, p. I6o. 
allowed to wither for six, twelve, and forty-seven hours respectively, dipped in water and dried, and again weighed. Immediately after this last weighing the shoots were immersed in water, and the weight again determined after an interval of a varying number of hours. The results are shown in Table IX, at a, b, c. The remaining figures show the results of other similar experiments with the same plant. Shoots d and e showed a wellmarked absorption of water after only two hours' immersion, and e withstood without any apparent injury two successive periods of withering; shoots $f$ and $g$ were immersed in a $2 \%$ and $3 \%$ solution of common salt respectively, and consequently showed much less absorption than the others, which were immersed in water only.

\section{TABLE IX}

Surface Absorption in Salicornia annua after withering.

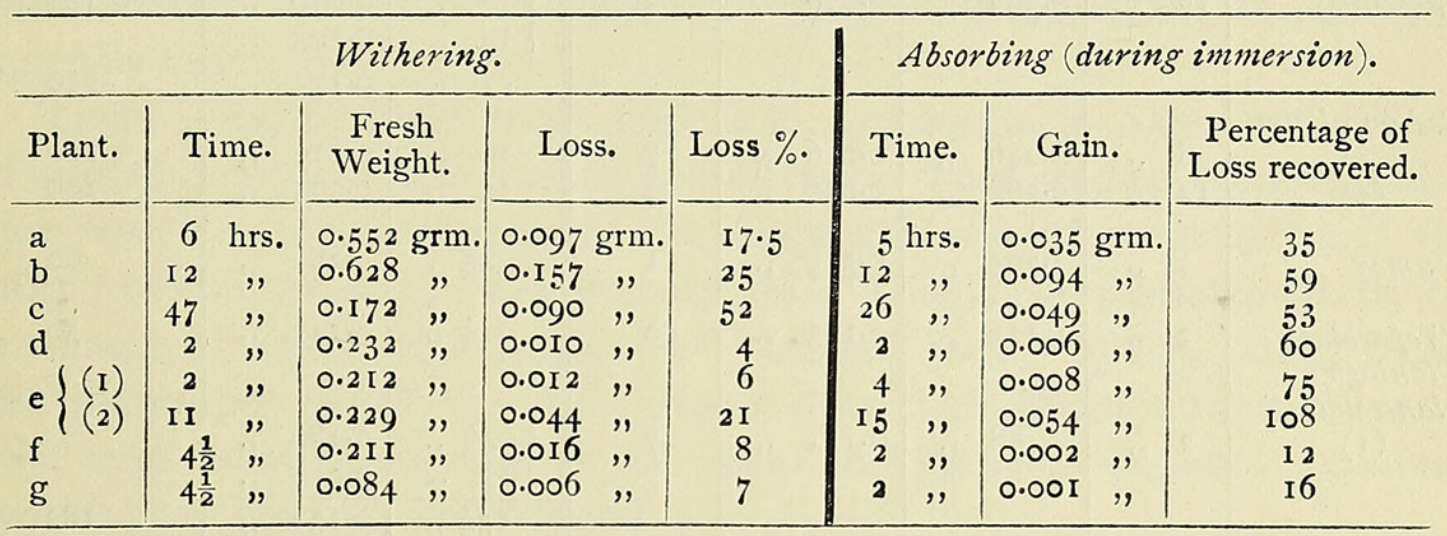

It will be seen from the figures in the last column that, with equal intervals of time for withering and absorbing, about half the water loss is regained. The absorption is thus a slower process than that of transpiration ; nevertheless, since these plants are frequently submerged in nature, it may often be of real advantage to the plant.

Finally, an experiment was made to determine whether a shoot of Salicornia could also absorb water vapour. For this purpose a detached, sealed shoot of Salicornia anmua was weighed and suspended in darkness in an almost saturated atmosphere for fourteen and a half hours. No visible condensation had taken place at the end of that time, but on weighing a gain of $2 \%$ had been made.

A few other halophytes which have been tested also show this power of absorbing water. In Table $\mathrm{X}$ are shown the results obtained with these, with Sedum, and with certain mesophytes. 
TABLE X

Surface Absorption in certain Halophytes and Mesophytes.

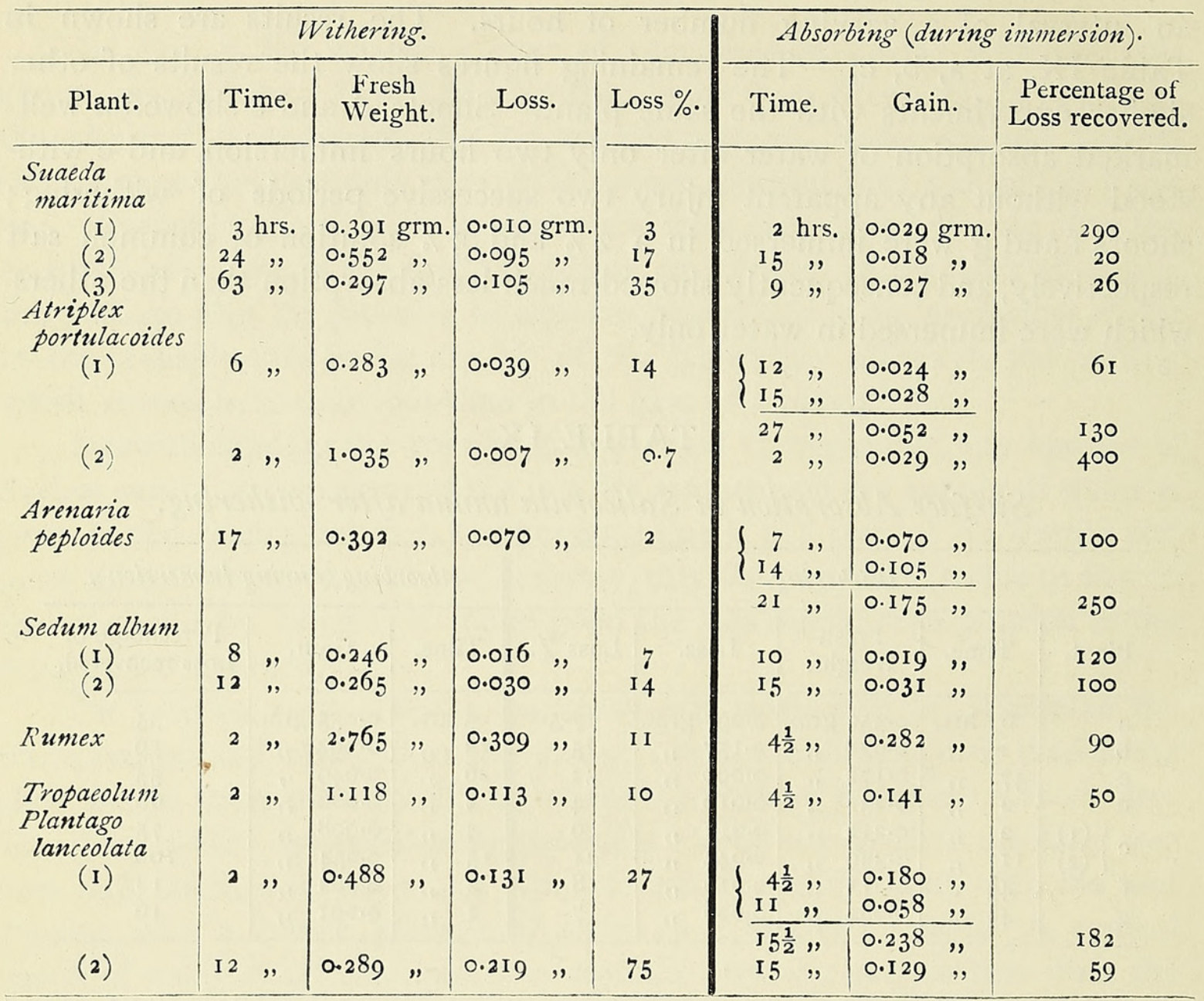

All these plants show a considerable power of surface absorption, ${ }^{1}$ and moreover, after immersion, the weight of the shoot is frequently greater than the initial fresh weight. Yet in every case freshly-gathered and apparently turgid shoots or leaves were used, and in the six succulent types, and in Plantago lanceolata among the mesophytes, it is almost impossible to tell at the moment of gathering whether or not the leaves are turgid at the beginning of the experiment. Plantago lanceolata is not itself a halophyte, but it comes very near to $P$. coronopus and $P$. maritima, which are typically marine; and perhaps $P$. lanceolata is itself a facultative halophyte. At least it appears that halophytes possess a considerable range in their normal water content, and a power of absorption over the green surface which in nature is probably capable of supplementing the root absorption by the utilization of rain ${ }^{2}$ and the standing water often found in a salt marsh.

${ }^{1}$ Cp. Pfeffer, W. ('00): Physiology of Plants, English Edition, vol. i, p. I60.

${ }^{2}$ Cp. Lundström, A. N. ('84) : Die Anpassungen der Pflanzen an den Regen und den Thatu. Henslow, Rev. Geo. ('08): The Absorption of Rain and Dew by Green Parts of Plants. 
Withering shoots of Suaeda and of Sedum album present a further point of similarity, since in both the old leaves act as water reservoirs for the young leaves at the growing apex. However, in Sedum each oldest leaf in turn yields up its water and shrivels $;{ }^{1}$ just before shrivelling a single short white rootlet appears, standing just above the insertion of the leaf at right angles to the stem which bears it. During such withering the youngest leaves appear not to suffer in the least from want of water, and the rate of transpiration is maintained almost unimpaired for as long as five or six weeks. In Suada, on the other hand, no such rootlets were seen, and the old leaves withered several together, whilst the young leaves were perceptibly flaccid, although much less so than the oldest ones. Suaeda will withstand desiccation for one week, Sedum for as long as six weeks.

The foregoing experiments, although scattered over different seasons and performed under different physical conditions, present, when taken together, sufficient evidence to show that the transpiration of at least some typical halophytes is by no means as reduced in character as has been frequently asserted.

There is indeed little or no cuticle in Salicornia, in Suaeda maritima, and probably also in some other halophytes. This renders a considerable water loss inevitable, in spite of the frequently closed stomata ${ }^{2}$ and the acidity ${ }^{3}$ of the cell-sap in the green parts. This is compensated partly by the storage of water in the aqueous tissue and partly by the power which these plants possess of absorbing water over their green surface, a power which must be of much value in the damp and yet often exposed situations in which they are frequently found.

\section{Behaviour of the Stomata in Halophytes.}

The behaviour of the stomata in halophytes was subjected to investigation by Stahl ${ }^{4}$ in I894, and by Rosenberg ${ }^{5}$ in 1897 , in both cases chiefly by means of the cobalt paper test.

Stahl found in this way that the stomata of certain halophytes which he had cultivated in an artificial salt marsh were constantly more or less widely open. He concluded that halophytes resembled freshwater marsh plants in possessing stomata which had lost the power to close.

Rosenberg applied the same method to the leaves of halophytes immediately after they had been detached from the plant growing in situ. In all the cases examined by him the stomata, open at first, closed shortly

${ }_{1}$ Cp. Pringsheim, E. ('06): Wasserbewegung und Turgorregulation in welkenden Pflanzen.

${ }^{2}$ Cp. Rosenberg, O. ('97): Ueber die Transpiration der Halophyten.

3 Aubert, E. ('92): Turgescence et transpiration des plantes grasses. Ann. des Sci. Nat., 1892.

4 Stahl ('94): Einige Versuche über Transpiration und Assimilation. Botanische Zeitung, I 894. Förhandl.

Rosenberg ('97): Über die Transpiration der Halophyten. Öfvers. af K. Vetensk. Akad. 
after the leaf was detached, and this was accompanied by a well-marked diminution in the rate of transpiration. Some of Rosenberg's plants (e.g. Aster tripolium) were the same as those previously used by Stahl, and he therefore concluded that the permanentlyopen stomata of Stahl's experiments must have been the result of cultivation, rather than a natural phenomenon. The results of both these workers are opposed to Schimper's view of the reduced nature of the transpiration in these plants.

It would seem worth while to investigate the whole question of the stomata of halophytes in more detail, both on account of the discrepancy in these results, and also from the point of view of the influence of these organs on the process of transpiration; but this has had to be deferred. The following observations are therefore of a preliminary nature; but they indicate clearly a power of movement in the stomata of some halophytic genera, as already asserted by Rosenberg.

In the first place the distribution of the stomata was determined for such types as were available. The numbers are given in Table XI, and each figure represents the mean of ten, or sometimes twelve, countings from strips of epidermis taken from adult leaves and examined fresh. It will be seen that whilst there are comparatively few stomata in Suaeda and in Arenaria peploides, there are many in Salicornia annua, which compares in this respect more nearly with a typical mesophyte, such as Vicia cracca. The distribution of stomata in halophytes is therefore a variable feature, and throws but little light on the problem of transpiration in these plants.

\section{TABLE XI}

Distribution of Stomata in Halophytes.

$\quad$ Type.
Suacda maritima
Arenaria peploides
Aster tripolium
Salicornia annua
Sedum album
Vicia cracca

\begin{tabular}{|c|c|c|}
\hline $\begin{array}{l}\text { Stomata pe } \\
\text { Lower epidermis }\end{array}$ & Stomata per & 6,3 \\
\hline & , & \\
\hline & , & \\
\hline $\mathrm{Fl}$ & & Io, \\
\hline $\mathrm{r}$ & ides & \\
\hline $\begin{array}{l}\text { Lower } \\
\text { Lower }\end{array}$ & & \\
\hline
\end{tabular}

In estimating the distribution of the stomata in Salicornia it was found that the number and size of the stomata varied much with the age of the internode from which the epidermis was taken. In one plant which had nine internodes in all, and which was six inches in height, epidermis from each internode was examined fresh, and the results are given in Table XII. The internodes are numbered from below upwards, and each number in the first column is the mean of ten readings, whilst the numbers in the remaining columns represent the mean of five readings. In each case the strip of epidermis was examined fresh, and mounted dry. 


\section{TABLE XII}

\section{Distribution and Size of Stomata taken from Different Regions of Salicornia anmua.}

\begin{tabular}{|c|c|c|c|c|c|}
\hline $\begin{array}{l}\text { No. of In- } \\
\text { ternode. }\end{array}$ & $\begin{array}{l}\text { No. of Stomata } \\
\text { per sq. } \mathrm{cm} \text {. }\end{array}$ & $\begin{array}{l}\text { Condition of } \\
\text { Stomata. }\end{array}$ & $\begin{array}{l}\text { Mean Diameter of } \\
\text { both Guard Cells. }\end{array}$ & $\begin{array}{l}\text { Diameter } \\
\text { of Rift. }\end{array}$ & $\begin{array}{l}\text { Diameter } \\
\text { of Pore. }\end{array}$ \\
\hline $\begin{array}{r}\text { I } \\
\text { II } \\
\text { IV } \\
\text { VI } \\
\text { VIII } \\
\text { IX }\end{array}$ & $\begin{array}{r}10,500 \\
9,750 \\
\text { II } 8775 \\
23,125 \\
23,625 \\
18,750\end{array}$ & $\begin{array}{l}\text { Widely open } \\
\text { Half shut } \\
\text { Half shut } \\
\text { Widely open } \\
\text { Widely open } \\
\text { Unopened }\end{array}$ & $\begin{array}{l}40 \mu \\
22, " \\
26, " \\
22, " \\
16, " \\
-\end{array}$ & $\begin{array}{l}20 \mu \\
10 " \\
= \\
= \\
-\end{array}$ & $\begin{array}{l}20 \mu \\
4 ", \\
5 ", \\
2 ", \\
2 ", \\
-\end{array}$ \\
\hline
\end{tabular}

In internodes VI and VIII the stomata were fully formed and open, but the epidermal cells were much smaller than on lower internodes, and probably neither these nor the guard cells had reached their full size. In internode IX the epidermal cells were in a state of active cell-division-the stoma mother-cells were in some cases just cut off; in others they had

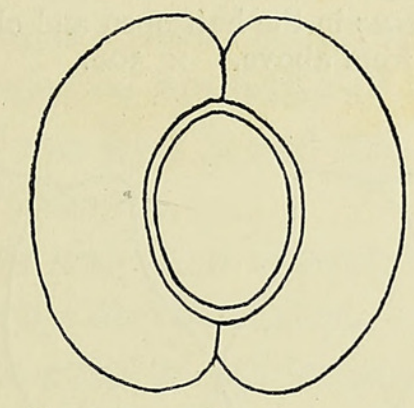

A (from I)

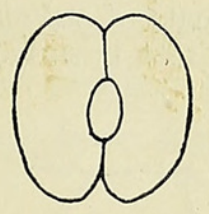

$B($ from VIII)

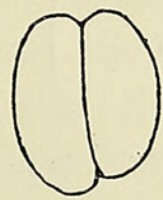

$C$ (from IX)

FIG. II. Outline of stomata taken from the lowest and two uppermost internodes respectively of a shoot of Salicornia; drawn to scale and $\times 500$.

just divided to form the guard cells, but in no case had any aperture been formed. It is of some interest to note that the guard cells in the upper and younger internodes open long before the stomata reach their full size. Typical stomata are shown drawn to scale in outline only in Fig. I I.

Some observations were made as to the effects of light and darkness on the stomata of Salicornia anmua and S. ramosissima. From experiments made on July I4, I909, it was found that stomata, previously half open, closed within three hours when placed in a dark room at nearly the same temperature and relative humidity. In this condition the pore appeared completely closed, but the rift was in every case still visible; within ten minutes all the stomata began to open, presumably owing to the illumination of the microscope stage. Measurements were made of the stomata in the open and closed condition, and from these and from the outlines shown in Figs. I 2 and I3, it appeared that guard cells expand 
both in the outward and downward direction when the pore opens, and conversely, the total diameter and the depth of the guard cells diminishes on closing : most commonly the rift is still obvious when the pore appears to be completely closed.

In September, October, and November, 1910, fresh material of Salicornia annua from various sources was examined for stomata. In some plants obtained from Burnham-on-Crouch in late September, the stomata were all closed and did not open when placed in either a damp or dry
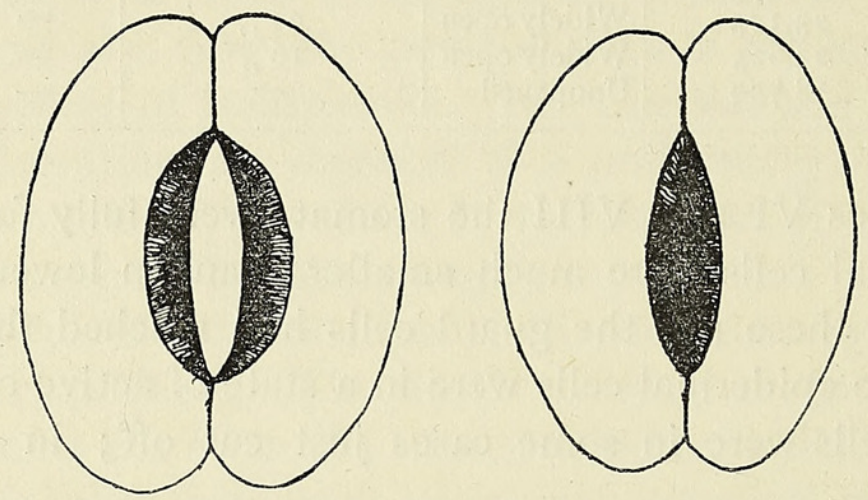

FIG. I2. Outline drawing of stomata of Salicornia annua in the half-open and closed condition respectively, seen in surface view from above. $\times 500$.
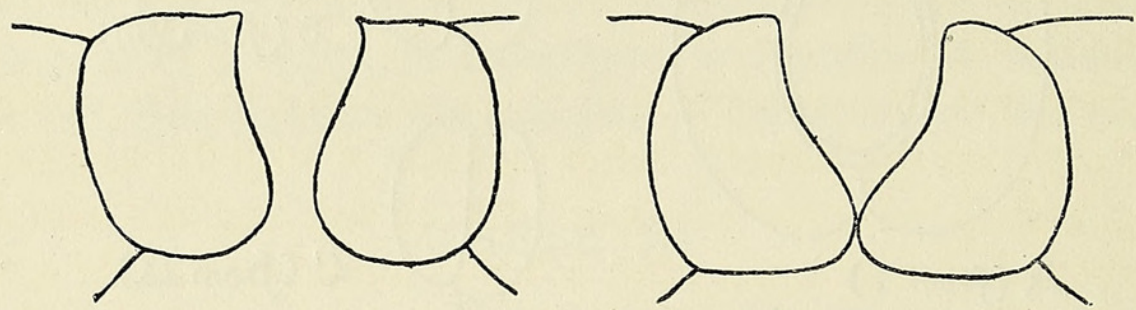

FIG. 13. Outline drawing of stomata of Salicornia ansua in the half-open and closed condition respectively, but seen in cross-section. $\times 500$.

atmosphere, with sunlight or bright diffuse light. The guard cells appeared to be turgid, but no opening was visible, and even when a strip of epidermis was mounted in water and exposed to bright diffuse light, only a narrow slit-like opening appeared. These plants were in their flowering period.

Other plants from Cley, received early in October, bore young seeds, and the stomata on these shoots behaved similarly; whilst material from Southampton later in the same month, and from Rye early in November, bore stomata which were all closed, and which seemed to have entirely lost the power of movement. It thus appears that in Salicornia anmua, and presumably also in other annual species of the same genus, the stomata begin to lose their capacity for movement during the flowering season, and finally remain permanently closed.

The stomata of Aster tripolium are found on both sides of the leaf; they are from four to five times larger than those of Salicornia anmu, 
and are therefore much easier of observation. Plants examined from the Cambridge Botanic Gardens in July, 1909, and others growing in an artificial salt marsh in Dulwich, in September, 1910, possessed stomata, the guard cells of which moved with ease and rapidity. This is contrary to the result of Stahl, ${ }^{1}$ who found that in his cultivated halophytes the stomata were open, but immovable.

In the artificial salt marsh at Dulwich there was but one plant of Aster tripolium. This had been grown for some months successfully, and had been watered at intervals with a $2 \%$ solution of common salt. At 8 a.m. on September 20, just before the sun was on this part of the marsh, a strip of epidermis was removed from both sides of one of the leaves, mounted dry and examined on the spot under a microscope. The stomata were widely open in each case, but they half closed whilst still under observation in less than three minutes. At this time the relative humidity in the neighbourhood of the plant was found to be $93.5 \%$. The whole plant was now darkened for an hour by being covered with dense black cloth. A strip of epidermis from one of these darkened leaves showed about half the stomata with the pore narrowly open, whilst the remainder had the pore completely closed as far as could be seen in surface view. The relative humidity of the air around the plant during the time of darkening was $93.1 \%$, and this change is so slight as to have a negligible effect on the stomata.

The plant was then uncovered and was exposed to the sunlight, which now fell directly on the leaves. After an hour of such illumination half the stomata on a strip of epidermis were still closed, and the remainder had the pore about half-way open; the relative humidity had, however, fallen to $78 \%$, and very shortly after all the leaves stood less erect and began to appear limp and flaccid.

Some fine plants of Aster tripolium were received in November, I9IO. These had many large and healthy leaves, all of which showed only closed stomata. Exposure to sunlight, bright diffuse light, and to electric light, either in dry air or nearly saturated air, did not cause these stomata to open, and this may have been due to the temperature or, more probably, to the time of year.

From the foregoing observations it may be concluded that the stomata of Salicornia and of Aster tripolium (two of the most typical British halophytes) do not show the features characteristic of either a xerophilous plant, as Schimper's theory would lead one to expect, or of a freshwater marsh plant as Stahl supposed. They rather resemble those of a typical mesophyte in being superficially placed, capable of opening and closing, and sensitive to light and to changes in the humidity of the atmosphere.

From preliminary observations it may be added that the stomata of

1 Stahl, E. ('94): Einige Versuche über Transpiration und Assimilation. Bot. Zeit., 1894.

L 12 
Sedum acre and of Sedum album are similarly unprotected and mesophytic in character, and these plants also show a high rate of transpiration per unit area. In the course of these experiments the epidermis of plants of Suceda maritima has often been examined, but the stomata have never been found open; the same is true of the minute stomata of Atriplex portulacoides, which are further protected by a scaly covering of epidermal hairs.

\section{Summary AND CONCLUSIONS.}

In the course of this paper it has been shown that:-

I. Salicornia annua and Suaeda maritima, both typical halophytes, have a high rate of transpiration per unit of surface area which is comparable with, or even greater than, that of a typical mesophyte, such as Vicia faba.

2. The transpiration rates obtained for these plants are not necessarily maximal, since no precaution was taken to ensure that the plants were absolutely turgid initially, and that the stomata were open; probably with wholly favourable conditions a still more rapid loss of water would ensue. The extent to which the rate of transpiration varies with the age of the plant has not yet been determined.

3. When not already turgid these plants are able to absorb water freely over their whole surface ; in this respect they resemble certain mesophytes, such as species of Plantago and Rumex. They have, however, unlike mesophytes, a certain capacity for storing water.

4. The stomata in Salicornia annua and in Aster tripolium are not sunken and are not protected by cuticle to any extent ; they have a distinct power of movement, and close in darkness. The stomata of Salicornia appear to lose their power of movement after the flowering period, and then remain permanently closed; those of Aster tripolium were also sensitive to the relative humidity of the atmosphere, being found open in the month of September in air nearly saturated with water vapour, and closed shortly afterwards on the same plant in air of $75 \%$ relative humidity: in winter this power of movement diminishes, or perhaps completely disappears.

5. Observations on the transpiration and stomatal behaviour of other halophytic plants are needed before any conclusions applicable to the whole group of plants can be made.

\section{REFERENCES.}

Aubert, E. ('92): Turgescence et Transpiration des Plantes grasses. Ann. des Sci. Nat., I892. Henslow, Rev. George ('08): The Absorption of Rain and Dew by Green Parts of Plants. Journ. Roy. Hort. Soc., London, I908.

JosT, Dr. L. ('07) : Lectures on Plant Physiology. English Edition, p. 97. 
LeSAGE, P. ('90): Recherches expérimentales sur les modifications des feuilles chez les plantes maritimes. Revue générale de Botanique, 1890.

Livingston, B. E. ('06): The Relation of Desert Plants to Soil, Moisture, and to Evaporation. Carnegie Institute of Washington, No. 5 .

Lundström, A. N. ('84) : Die Anpassungen der Pflanzen an den Regen und den Thau. Nova Acta reg. Soc. Scientiarum Upsaliensis, vol. xii, 1884.

Pfeffer, W. ('06): The Physiology of Plants. English Edition.

Pringsheim, E. ('06): Wasserbewegung und Turgorregulation in welkenden Pflanzen. Jahrbücher für wiss. Bot., 1906.

Rosenberg, O. ('97) : Über die Transpiration der Halophyten. Öfvers. af Kongl. Vetenskaps-Akad. Förhandlingar, Stockholm, I 897 .

Schimper, A. F. W. ('91): Die indomalayische Strandflora, Jena, i89i.

Stahl, E. ('94): Einige Versuche über Transpiration und Assimilation. Bot. Zeitung, Leipzig, I894.

Thoday, D. ('09): Experimental Researches on Vegetable Assimilation and Respiration. V. A Critical Examination of Sachs' Method for using Increase of Dry Weight as a Measure of Carbon Dioxide Assimilation in Leaves. Proc. Roy. Soc., B., vol. lxxxii, I909. 


\section{$2 \mathrm{BHL}$ Biodiversity Heritage Library}

Delf, Ellen Marion. 1911. "Transpiration and behaviour of stomata in Halophytes." Annals of botany 25, 485-505.

https://doi.org/10.1093/oxfordjournals.aob.a089338.

View This Item Online: https://www.biodiversitylibrary.org/item/236971

DOI: https://doi.org/10.1093/oxfordjournals.aob.a089338

Permalink: https://www.biodiversitylibrary.org/partpdf/319846

\section{Holding Institution}

Smithsonian Libraries

\section{Sponsored by}

Biodiversity Heritage Library

\section{Copyright \& Reuse}

Copyright Status: Not in copyright. The BHL knows of no copyright restrictions on this item.

This document was created from content at the Biodiversity Heritage Library, the world's largest open access digital library for biodiversity literature and archives. Visit BHL at https://www.biodiversitylibrary.org. 